\title{
Subolesin expression in response to pathogen infection in ticks
}

\author{
Zorica Zivkovic ${ }^{1 *}{ }^{*}$, Alessandra Torina ${ }^{2 \dagger}$, Ruchira Mitra ${ }^{3+}$, Angela Alongi $^{2}$, Salvatore Scimeca ${ }^{2}$, Katherine M Kocan ${ }^{3}$, \\ Ruth C Galindo ${ }^{4}$, Consuelo Almazán ${ }^{5}$, Edmour F Blouinn ${ }^{3}$, Margarita Villar ${ }^{4}$, Ard M Nijhof ${ }^{1}$, Rinosh Mani ${ }^{3}$, \\ Giuseppa La Barbera², Santo Caracappa ${ }^{2}$, Frans Jongejan ${ }^{1,6}$, José de la Fuente ${ }^{3,4^{*}}$
}

\begin{abstract}
Background: Ticks (Acari: Ixodidae) are vectors of pathogens worldwide that cause diseases in humans and animals. Ticks and pathogens have co-evolved molecular mechanisms that contribute to their mutual development and survival. Subolesin was discovered as a tick protective antigen and was subsequently shown to be similar in structure and function to akirins, an evolutionarily conserved group of proteins in insects and vertebrates that controls NF-kB-dependent and independent expression of innate immune response genes. The objective of this study was to investigate subolesin expression in several tick species infected with a variety of pathogens and to determine the effect of subolesin gene knockdown on pathogen infection. In the first experiment, subolesin expression was characterized in ticks experimentally infected with the cattle pathogen, Anaplasma marginale. Subolesin expression was then characterized in questing or feeding adult ticks confirmed to be infected with Anaplasma, Ehrlichia, Rickettsia, Babesia or Theileria spp. Finally, the effect of subolesin knockdown by RNA interference (RNAi) on tick infection was analyzed in Dermacentor variabilis males exposed to various pathogens by capillary feeding (CF).
\end{abstract}

Results: Subolesin expression increased with pathogen infection in the salivary glands but not in the guts of tick vector species infected with $A$. marginale. When analyzed in whole ticks, subolesin expression varied between tick species and in response to different pathogens. As reported previously, subolesin knockdown in D. variabilis infected with $A$. marginale and other tick-borne pathogens resulted in lower infection levels, while infection with Francisella tularensis increased in ticks after RNAi. When non-tick-borne pathogens were fed to ticks by CF, subolesin RNAi did not affect or resulted in lower infection levels in ticks. However, subolesin expression was upregulated in D. variabilis exposed to Escherichia coli, suggesting that although this pathogen may induce subolesin expression in ticks, silencing of this molecule reduced bacterial multiplication by a presently unknown mechanism.

Conclusions: Subolesin expression in infected ticks suggested that subolesin may be functionally important for tick innate immunity to pathogens, as has been reported for the akirins. However, subolesin expression and consequently subolesin-mediated innate immunity varied with the pathogen and tick tissue. Subolesin may plays a role in tick innate immunity in the salivary glands by limiting pathogen infection levels, but activates innate immunity only for some pathogen in the guts and other tissues. In addition, these results provided additional support for the role of subolesin in other molecular pathways including those required for tissue development and function and for pathogen infection and multiplication in ticks. Consequently, RNAi experiments demonstrated that subolesin knockdown in ticks may affect pathogen infection directly by reducing tick innate immunity that results

\footnotetext{
*Correspondence: Z.Zivkovic@uu.nl; jose_delafuente@yahoo.com

+ Contributed equally

${ }^{1}$ Department of Infectious Diseases and Immunology, Utrecht Centre for

Tick-borne Diseases (UCTD), Faculty of Veterinary Medicine, Utrecht University, Yalelaan 1, 3584CL, Utrecht, The Netherlands

${ }^{3}$ Department of Veterinary Pathobiology Center for Veterinary Health

Sciences, Oklahoma State University, Stillwater, OK 74078, USA
} 


\section{in higher infection levels and indirectly by affecting tissue structure and function and the expression of genes that interfere with pathogen infection and multiplication. The impact of the direct or indirect effects of subolesin knockdown on pathogen infection may depend on several factors including specific tick-pathogen molecular interactions, pathogen life cycle in the tick and unknown mechanisms affected by subolesin function in the control of global gene expression in ticks.}

\section{Background}

Ticks transmit pathogens of the genera Anaplasma, Ehrlichia, Rickettsia, Babesia and Theileria that impact both human and animal health [1-3]. Of these tickborne pathogens, Anaplasma marginale causes the economically important cattle disease, bovine anaplasmosis [2]. Worldwide, A. marginale is vectored by tick species of the genera Dermacentor and Rhipicephalus [1-3]. The developmental cycle of $A$. marginale, which is presently the most completely characterized rickettsial cycle in ticks, is complex and coordinated with tick feeding cycle [4-6]. Ticks become infected with $A$. marginale when they ingest infected bovine erythrocytes in the bloodmeal, and the first sites of infection are in gut and Malpighian tubule cells. After a second tick feeding, A. marginale infects and develops in salivary glands, the site of transmission to the vertebrate host.

The ticks and the pathogens that they transmit have co-evolved molecular interactions involving genetic traits of both the tick and the pathogen that mediate their development and survival [7]. Recent studies have shown that pathogen infection modifies the expression of subolesin and other tick genes [7-11]. Tick subolesin was discovered as a tick protective antigen in Ixodes scapularis [12]. Subolesin was shown by RNAi gene knockdown and immunization trials using the recombinant protein to protect hosts against tick infestations, reduce tick survival and reproduction, cause degeneration of guts, salivary glands, reproductive tissues and embryos and to decrease the vector capacity of ticks for $A$. marginale and A. phagocytophilum [8,13-18]. In addition, subolesin was shown to be similar in structure and function to insect and vertebrate akirins which control NF$\mathrm{kB}$-dependent and independent gene expression that impact innate immunity [19-22]. Based on the proposed function for tick subolesin, this molecule would be involved in the initial host innate immune response to pathogen infection. However, subolesin expression and its role in tick innate immunity to pathogen infection have not been reported.

The objective of this study was to investigate subolesin expression in several tick species infected with a variety of pathogens and to determine the effect of subolesin gene knockdown on pathogen infection.

\section{Results}

Expression of subolesin in tick vectors experimentally infected with $A$. marginale

Subolesin expression was analyzed in the tick vector species, D. variabilis, D. andersoni, D. reticulatus, $R$. sanguineus, $R$. microplus and $R$. annulatus experimentally infected with $A$. marginale. Characterization of subolesin expression in guts and salivary glands was done in $D$. variabilis, $D$. andersoni and $R$. sanguineus. Differences in subolesin expression were observed between guts and salivary glands when correlated with $A$. marginale infection in $D$. variabilis, D. andersoni and $R$. sanguineus (Figures 1A-F). While subolesin expression in salivary glands correlated positively with pathogen infection in all three tick species (correlation coefficient, $\mathrm{R}^{2}=0.7,0.6$ and 0.9 , for $D$. variabilis, $D$. andersoni and $R$. sanguineus, respectively; Figures $1 \mathrm{~A}-\mathrm{C})$, a correlation was not found in guts $\left(\mathrm{R}^{2}=0.1,0.3\right.$ and 0.2, respectively; Figures 1D-F). Interestingly, as shown by differences in the linear correlation slope, the increase in pathogen infection levels resulted in larger variations in subolesin expression in R. sanguineus (Figure 1C) as compared to Dermacentor spp. (Figures 1A and 1B).

When subolesin expression was analyzed in whole ticks, differences were observed in response to A. marginale infection between tick species, but in all cases subolesin levels remained unchanged (4 of 6 species analyzed) or were significantly lower in infected ticks than in the uninfected controls (2 of 6 species analyzed) (Figure 2). However, notable tick-to-tick variation in subolesin expression was also observed (Figure 2).

\section{Subolesin expression in questing and feeding adult ticks naturally infected with Anaplasma, Ehrlichia, Rickettsia, Babesia or Theileria species}

To characterize subolesin expression in ticks naturally infected with different pathogens, questing and feeding adult ticks were collected and analyzed for pathogen infection. The ticks were found to be infected with various pathogens: $R$. sanguineus and $D$. marginatus were infected with Rickettsia conorii; $R$. bursa was infected with Theileria annulata; Hyalomma lusitanicum was infected with Babesia bigemina; Hyalomma marginatum marginatum was infected with Theileria buffeli; $R$. sanguineus was infected with Ehrlichia canis; and R. turanicus and $R$. bursa were infected with $A$. ovis (Table 1). 


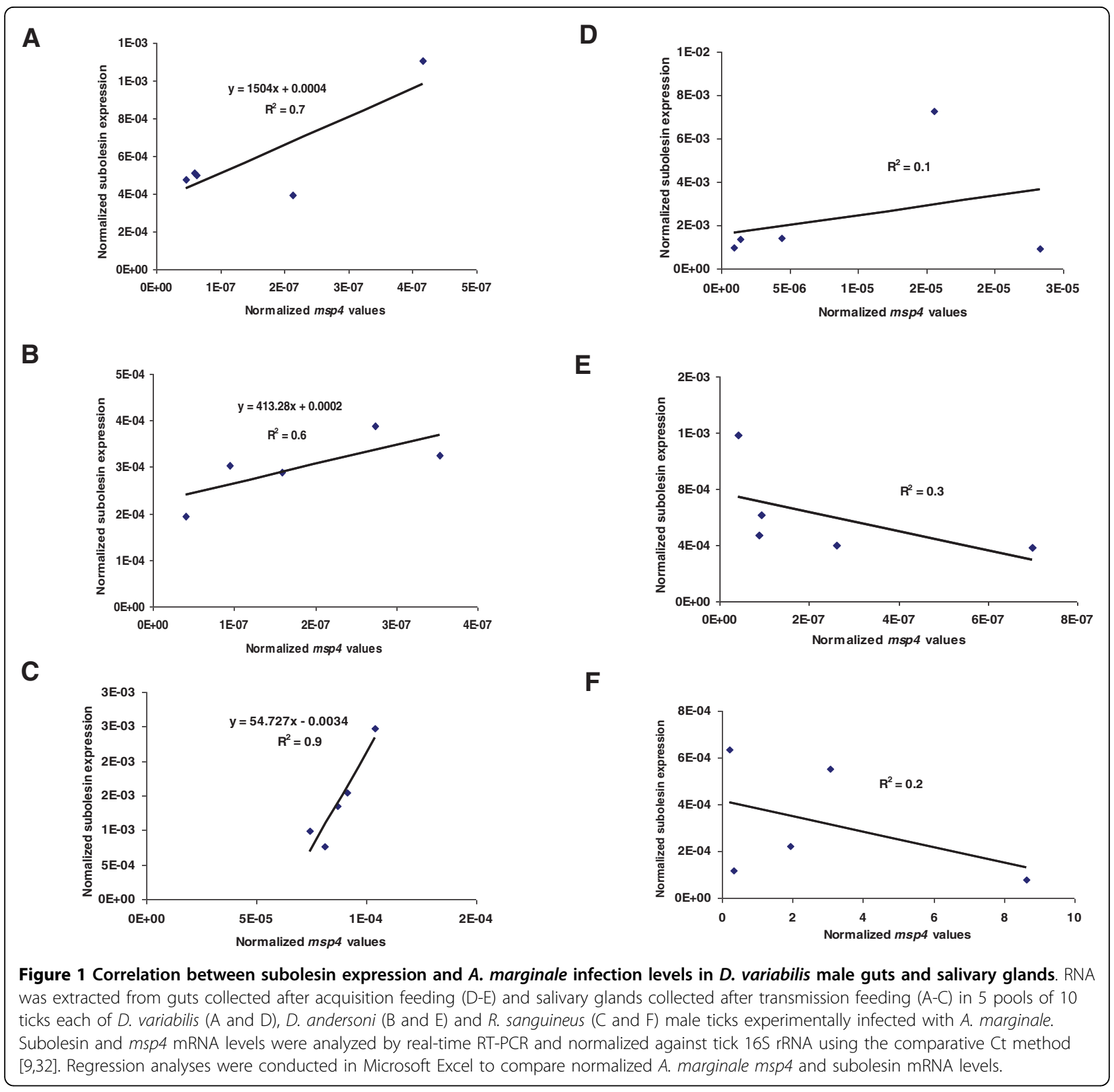

Subolesin mRNA levels were analyzed in infected ticks and in sex and collection-matched uninfected controls. Under natural infection conditions, differences in subolesin expression were observed between tick species in response to different pathogens (Figures 3A-D). However, similar to ticks experimentally infected with $A$. marginale, subolesin levels remained unchanged or were lower in infected ticks as compared with uninfected controls (Figures 3A-D) with the exception of $H$. lusitanicum infected with B. bigemina (Figure $3 \mathrm{~B}$ ). Tick-to-tick variations in subolesin expression were also observed as shown previously in ticks experimentally infected with $A$. marginale (Figures 3A-D). When analysis was conducted in the same tick species infected with different pathogens, $R$. sanguineus infected with $R$. conorii or $E$. canis (Figures $3 \mathrm{~A}$ and $3 \mathrm{D}$ ) and $R$. bursa infected with T. annulata or $A$. ovis (Figures $3 \mathrm{~B}$ and $3 \mathrm{C}$ ), subolesin expression levels did not differ with the pathogen and were similar between infected and uninfected ticks.

\section{Effect of subolesin knockdown on the tick response to pathogen infection}

The results of subolesin expression studies in response to pathogen infection suggested a role for this molecule in tick innate immunity, at least in salivary glands and in whole ticks in response to some pathogens. 


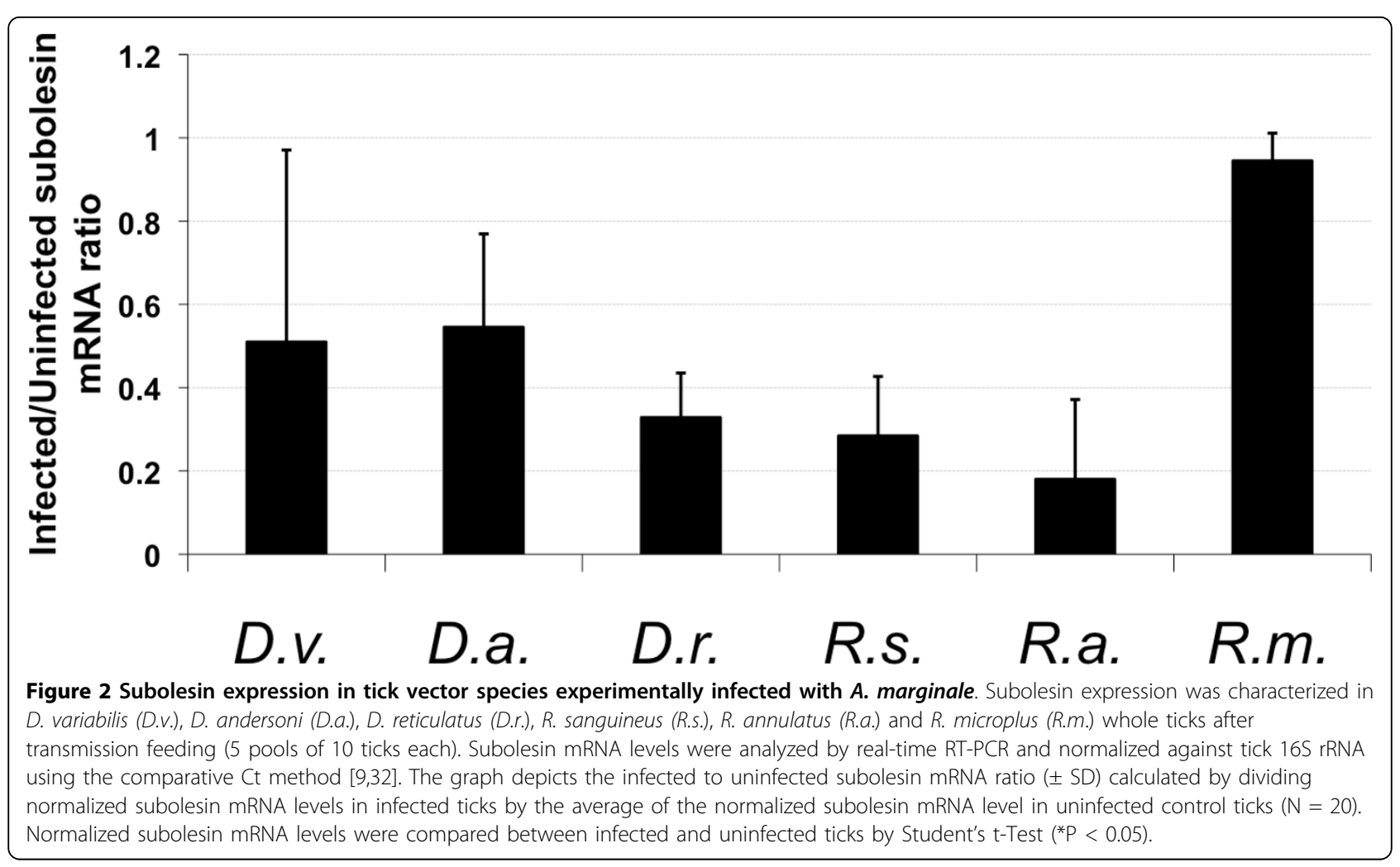

Table 1 Adult ticks naturally infected with Anaplasma, Ehrlichia, Rickettsia, Babesia or Theileria species

\begin{tabular}{lccc}
\hline Tick species ( $)$ & Sex & Collection & Pathogen infection \\
\hline R. sanguineus (3) & female & questing & R. conorii \\
\hline D. marginatus (3) & female & questing & R. conorii \\
\hline R. bursa (9) & female & sheep & T. annulata \\
\hline H. lusitanicum (5) & male & questing & B. bigemina \\
\hline H. m. marginatum (8) & male & cattle & T. buffeli \\
\hline R. sanguineus (2) & female & dog & E. canis \\
\hline R. turanicus (2) & female & sheep & A. ovis \\
\hline$R$. bursa (3) & female & sheep & A. ovis \\
\hline
\end{tabular}

Questing and feeding adult ticks were collected in Sicilian farms and analyzed for pathogen infection by PCR or RLB. To define pathogen species infecting ticks, PCR and sequence analysis of cloned amplicons were performed for Anaplasma, Ehrlichia and Rickettsia spp. For Theileria and Babesia spp., RLB results were confirmed at the species level. For analysis of subolesin expression, sex and collection-matching uninfected controls were used. Uninfected ticks were negative for all pathogens analyzed.

To define the role of subolesin in tick innate immunity, the effect of subolesin gene knockdown was analyzed in $D$. variabilis males capillary fed Gram-positive and Gramnegative bacteria and the yeast, Pichia pastoris (Table 2). The results demonstrated that subolesin knockdown after RNAi was effective with an average of $55-99 \%$ gene silencing (Table 2). The effect of subolesin knockdown on tick infection levels varied among pathogens (Table 2). While Francisella tularensis infection levels were higher in subolesin-silenced ticks when compared to controls, the A. marginale, A. phagocytophilum, Ehrlichia canis and Escherichia coli levels were lower. Bacillus subtilis and $P$. pastoris infection levels were not significantly different between subolesin-silenced and control ticks.

To characterize the effect of pathogen infection by CF on subolesin expression, subolesin mRNA levels were compared between ticks injected with control dsRNA and then fed pathogen-infected or plain media by CF (Figure 4). The results demonstrated that, with the exception of the $E$. coli-fed ticks, subolesin levels remained unchanged or were lower in infected ticks. However, when subolesin expression was analyzed in individual ticks, some ticks in groups infected with E. coli, E. canis, A. marginale (Bison), $P$. pastoris and $A$. phagocytophilum had subolesin mRNA levels higher than the controls (Figure 5). This result explained the tick-to-tick variation observed in previous experiments with experimentally and naturally infected ticks and suggested that other factors affected subolesin expression independent of infection levels because subolesin expression only correlated positively with pathogen infection levels in F. tularensis-infected ticks (Figure 4 insert).

\section{Discussion}

Differential expression of subolesin in Anaplasmainfected tick guts and salivary glands and cultured tick cells was reported previously $[7,9,10]$. In these 


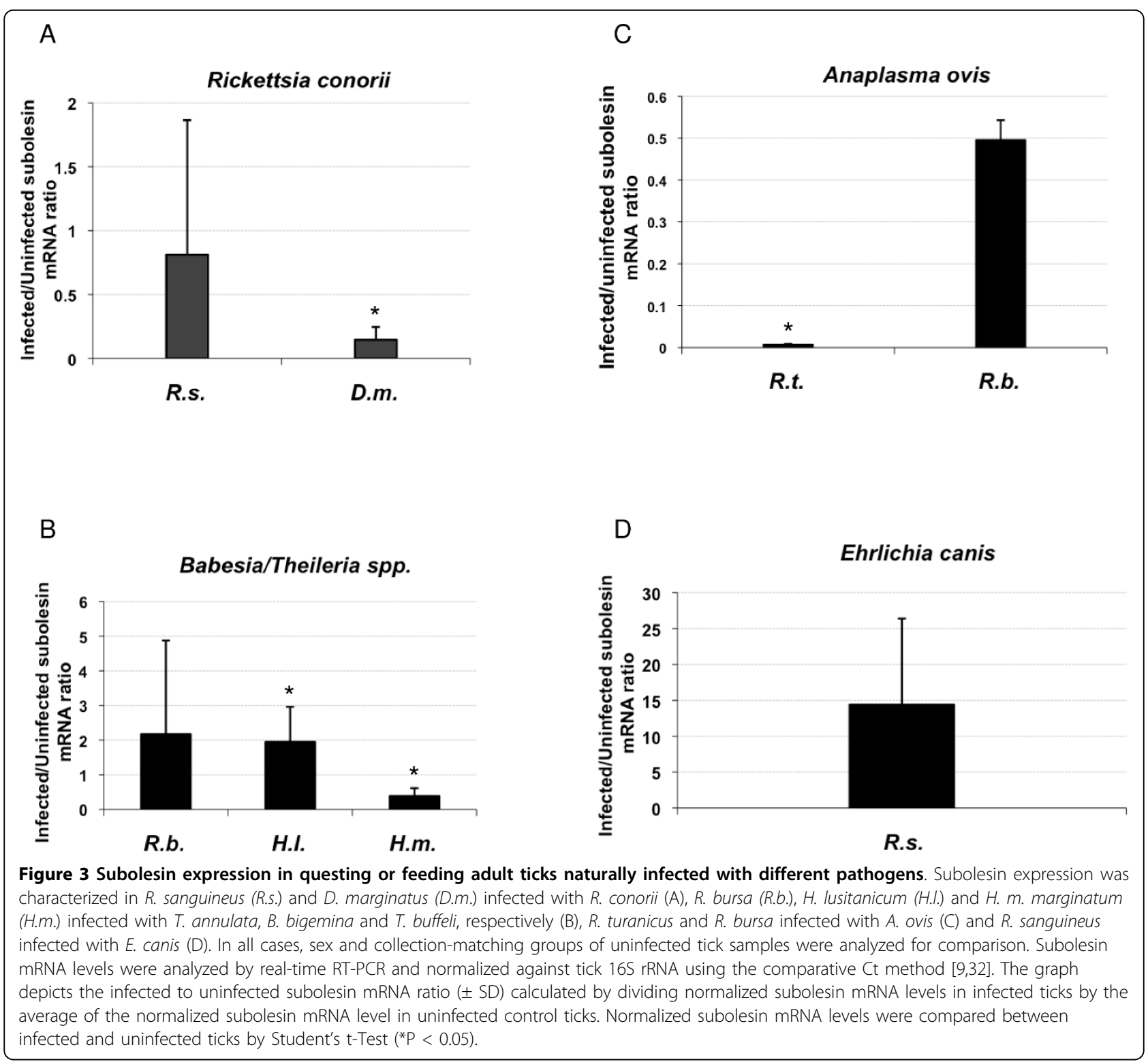

experiments, subolesin expression was significantly upregulated in $D$. variabilis salivary glands and IDE8 tick cells but not in $D$. variabilis guts and $R$. microplus salivary glands in response to infection with $A$. marginale [9]. In contrast to $A$. marginale, subolesin expression in A. phagocytophilum-infected I. scapularis nymphs was significantly downregulated and remained unchanged in infected ISE6 cultured tick cells [9]. The differences in expression patterns between $A$. marginale and $A$. phagocytophilum infected cultured tick cells were also recently demonstrated for other genes [11]. In addition, functional analysis by subolesin RNAi demonstrated that $A$. marginale infection levels were reduced in D. variabilis salivary glands and IDE8 tick cells after gene knockdown [8-10]. Subolesin knockdown affected
A. marginale development in $D$. variabilis by affecting rickettsial development and infection levels in different tissues [10]. Interestingly, salivary gland infections were not observed in these subolesin-silenced ticks, raising the question of whether they would have been able to transmit $A$. marginale [10]. Additionally, the function of subolesin was recently suggested to be similar to insect and vertebrate akirins in the control of NF-kB-dependent and independent gene expression in ticks [20,21]. These results suggested that subolesin expression would likely be affected by pathogen infection and to have a role on tick innate immunity, a hypothesis that was tested in the experiments reported herein.

Results reported herein (Table 1) further confirmed subolesin upregulation in salivary glands of $A$. marginale- 
Table 2 Experimental conditions and results of $D$. variabilis subolesin RNAi and CF with different pathogens

\begin{tabular}{|c|c|c|c|c|}
\hline $\begin{array}{l}\text { Pathogen } \\
\text { (isolate/strain) }\end{array}$ & Inoculum & CF tickmeal & $\begin{array}{c}\text { Subolesin expression } \\
\text { silencing } \\
(\%)^{\mathrm{a}}\end{array}$ & $\begin{array}{l}\text { Tick infection } \\
\text { ratio } \\
\text { (Subolesin/ }^{\text {Rs86) }}{ }^{\mathbf{b}}\end{array}$ \\
\hline $\begin{array}{l}\text { A. marginale } \\
\text { (Oklahoma, OK [33]) }\end{array}$ & $\begin{array}{l}4.3 \% \text { infected } \\
\text { erythrocytes }\end{array}$ & $\begin{array}{l}\text { Blood from splenectomized calves experimentally } \\
\text { infected with isolate stabilate }\end{array}$ & $89 \pm 17^{*}$ & $0.85 \pm 0.09^{*}$ \\
\hline $\begin{array}{l}\text { A. marginale } \\
\text { (Okeechobee, FL [33]) }\end{array}$ & $\begin{array}{l}3.3 \% \text { infected } \\
\text { erythrocytes }\end{array}$ & $\begin{array}{l}\text { Blood from splenectomized calves experimentally } \\
\text { infected with isolate stabilate }\end{array}$ & $55 \pm 32^{*}$ & $0.83 \pm 0.10^{*}$ \\
\hline $\begin{array}{l}\text { A. marginale } \\
\text { (Bison) [33] }\end{array}$ & $\begin{array}{l}7.4 \% \text { infected } \\
\text { erythrocytes }\end{array}$ & $\begin{array}{l}\text { Blood from splenectomized calves experimentally } \\
\text { infected with isolate stabilate }\end{array}$ & $86 \pm 17^{*}$ & $0.95 \pm 0.10^{*}$ \\
\hline $\begin{array}{l}\text { A. phagocytophilum } \\
\text { (NY18) [34] }\end{array}$ & $50 \%$ infected cells & ISE6 cultured tick cells in L15B with 10\% FBS & $92 \pm 14^{*}$ & $0.91 \pm 0.09^{*}$ \\
\hline $\begin{array}{l}\text { F. tularensis } \\
\text { (Live Vaccine Strain LVS; } \\
\text { ATCC 29684) }\end{array}$ & $10^{7} \mathrm{CFU} / \mathrm{ml}$ & DMEM with $10 \%$ FBS & $99 \pm 2^{*}$ & $1.74 \pm 0.86^{*}$ \\
\hline $\begin{array}{l}\text { E. canis } \\
\text { (Ebony) }\end{array}$ & $2 \%$ infected cells & DH82 cultured dog cells in DMEM with $10 \%$ FBS & $94 \pm 11^{*}$ & $0.89 \pm 0.16^{*}$ \\
\hline $\begin{array}{l}\text { E. coli } \\
\text { (JM109; Promega) }\end{array}$ & $10^{7} \mathrm{CFU} / \mathrm{ml}$ & DMEM with $10 \%$ FBS & $97 \pm 3^{*}$ & $0.92 \pm 0.07^{*}$ \\
\hline $\begin{array}{l}\text { B. subtilis } \\
\text { (culture 125-1 kindly supplied } \\
\text { by H. Evers) }\end{array}$ & $10^{7} \mathrm{CFU} / \mathrm{ml}$ & DMEM with $10 \%$ FBS & $71 \pm 21^{*}$ & $0.65 \pm 0.58$ \\
\hline $\begin{array}{l}\text { P. pastoris } \\
\text { (X33; Invitrogen) }\end{array}$ & $10^{6} \mathrm{CFU} / \mathrm{ml}$ & YPD & $80 \pm 16^{*}$ & $0.60 \pm 0.31$ \\
\hline
\end{tabular}

${ }^{a}$ Subolesin mRNA levels were determined by real-time RT-PCR and normalized against tick 16S rRNA using the comparative Ct method. Percent subolesin expression silencing was calculated in subolesin dsRNA-injected ticks with respect to control ticks injected with the unrelated Rs86 dsRNA and expressed as average \pm SD. Subolesin normalized Ct values were compared between subolesin dsRNA and control Rs86 dsRNA injected ticks by Student's t-test (*P < 0.05). ${ }^{b}$ Infection levels were determined by real-time PCR using pathogen-specific gene sequences and normalizing against tick $16 \mathrm{~S}$ rRNA using the comparative Ct method. Tick infection ratio was calculated as subolesin dsRNA to average control Rs 86 dsRNA injected ticks normalized Ct values and expressed as average \pm SD. Pathogen-specific gene normalized Ct values were compared between subolesin dsRNA and control Rs86 dsRNA injected ticks by Student's t-test ( ${ }^{*}$ < 0.05 ). Abbreviations: CF, capillary feeding; CFU, colony forming units; L15B, modification of Leibovitz's L15 medium containing additional glucose, amino acids, vitamins and trace minerals (Sigma-Aldrich, St Louis, MO, USA); FBS, fetal bovine serum (Sigma); DMEM, Dulbecco's Modified Eagle Medium (Gibco, Invitrogen, Carlsbad, CA, USA); YPD, Yeast Extract Peptone Dextrose medium (10 g/l yeast extract, $20 \mathrm{~g} / \mathrm{l}$ peptone, $20 \mathrm{~g} / \mathrm{l}$ glucose) (Sigma).

infected ticks. However, A. marginale infection did not affect subolesin expression in the gut of infected ticks. When subolesin expression was analyzed in whole ticks infected with various pathogens, expression levels remained generally unchanged or were lower in infected ticks. This result suggested that while subolesin expression may be upregulated in salivary glands, expression may not be affected or even decreased in other tissues of infected ticks. The overall effect of pathogen infection on subolesin expression in whole ticks may be different from that observed in isolated tissues and reinforces the role that different tissues play in pathogen infection and multiplication in ticks $[10,23]$. These results were similar to those obtained in I. scapularis nymphs infected with $A$. phagocytophilum but demonstrated differences in tick response to other pathogens, as illustrated by subolesin upregulation in $H$. lusitanicum infected with $B$. bigemina [9]. However, the results with naturally infected ticks should be taken with caution due to the small number of ticks analyzed. Furthermore, although naturally infected ticks were analyzed for the presence of the most prevalent tick-borne pathogens in Sicily, the infection with other pathogens not considered in these studies could affect subolesin expression levels in ticks [24]. However, it is likely that these pathogens would be present in both groups of ticks considered in the study, "infected" and "uninfected", therefore rendering no differences in subolesin mRNA levels.

As demonstrated herein, subolesin may play a role in tick innate immunity in salivary glands but not in the gut. Since the gut is the first tick barrier to pathogen infection [2], subolesin may not be involved in protecting ticks against $A$. marginale infection because of mechanisms that have co-evolved between the pathogen and the tick vector to support pathogen transmission while insuring tick survival [25]. However, subolesin may function in the salivary glands to limit pathogen infection to levels that are not detrimental for ticks. The differential role of subolesin in tick gut and salivary gland cells was further demonstrated by RNAi experiments $[7,9]$. Gene knockdown may not affect $A$. marginale infection levels in tick guts because subolesin may not be involved in innate immunity in this tissue. The decrease in $A$. marginale infection levels in the salivary glands of subolesin-silenced $D$. variabilis may not be related to innate immune response but may be due to 


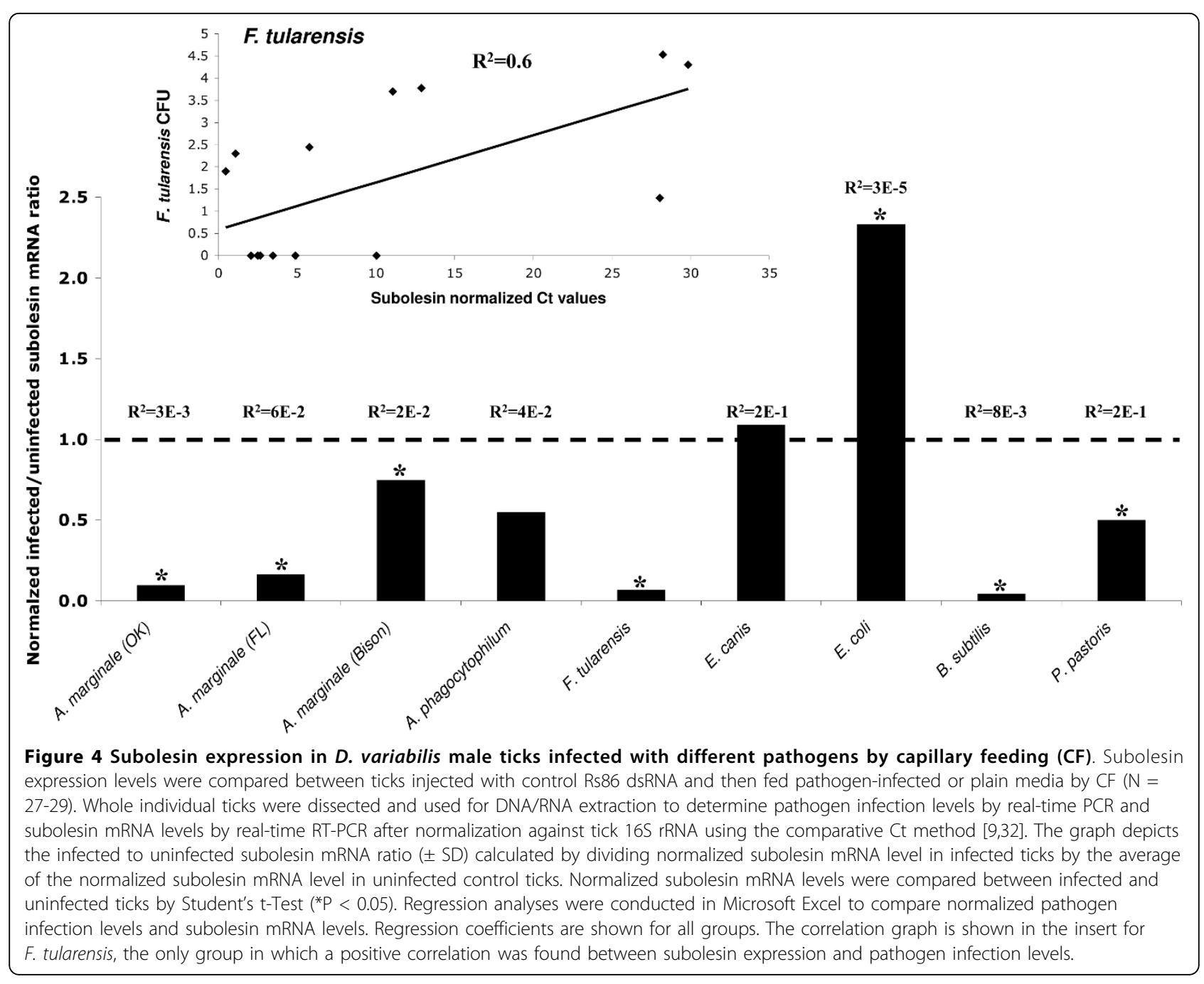

suppression of other genes regulated by subolesin and required for pathogen infection and multiplication $[7,19,20]$ and/or involved in salivary gland function $[10,15]$. This effect is most likely not relevant in the gut perhaps because gene silencing was shown to occur 3 days after injection of subolesin dsRNA [15], when gut cells may have already become infected with $A$. marginale.

Recently, we studied the role of $D$. variabilis defensin, varisin, in tick innate immunity to A. marginale [26]. Silencing of varisin occurred in tick hemocytes, midguts and salivary glands after RNAi. Varisin knockdown did not increase $A$. marginale infections, which actually were significantly reduced in the varisin-silenced ticks. However, A. marginale colonies were morphologically abnormal in varisin-silenced ticks when compared with the controls and some ticks had systemic infections with a yeast-like microbe that may have resulted from varisin RNAi. These results suggested that tick-pathogen interactions may have evolved in natural tick vector species to prevent innate immunity mechanisms against the vectored pathogen and to limit infection with non-tick vectored microorganisms.

The effect of subolesin knockdown in ticks on infection with tick-borne and non-tick-borne organisms was tested in D. variabilis using RNAi and CF. In these experiments, infection levels of the tick-borne pathogens, A. marginale, A. phagocytophilum and E. canis were lower in subolesin-silenced ticks. In contrast, $F$. tularensis infections were higher after subolesin RNAi and CF. These results could be explained in several ways: (1) as previously discussed, tick-pathogen interactions may have evolved in the natural tick vector species to prevent innate immunity against tick-borne pathogens; (2) the life cycle of pathogens in ticks varies and may be accompanied by different impacts of subolesin expression; (3) although D. variabilis has been demonstrated to be a vector for F. tularensis [27], as shown herein, subolesin function in innate immunity could differ among pathogens; (4) subolesin control of gene 


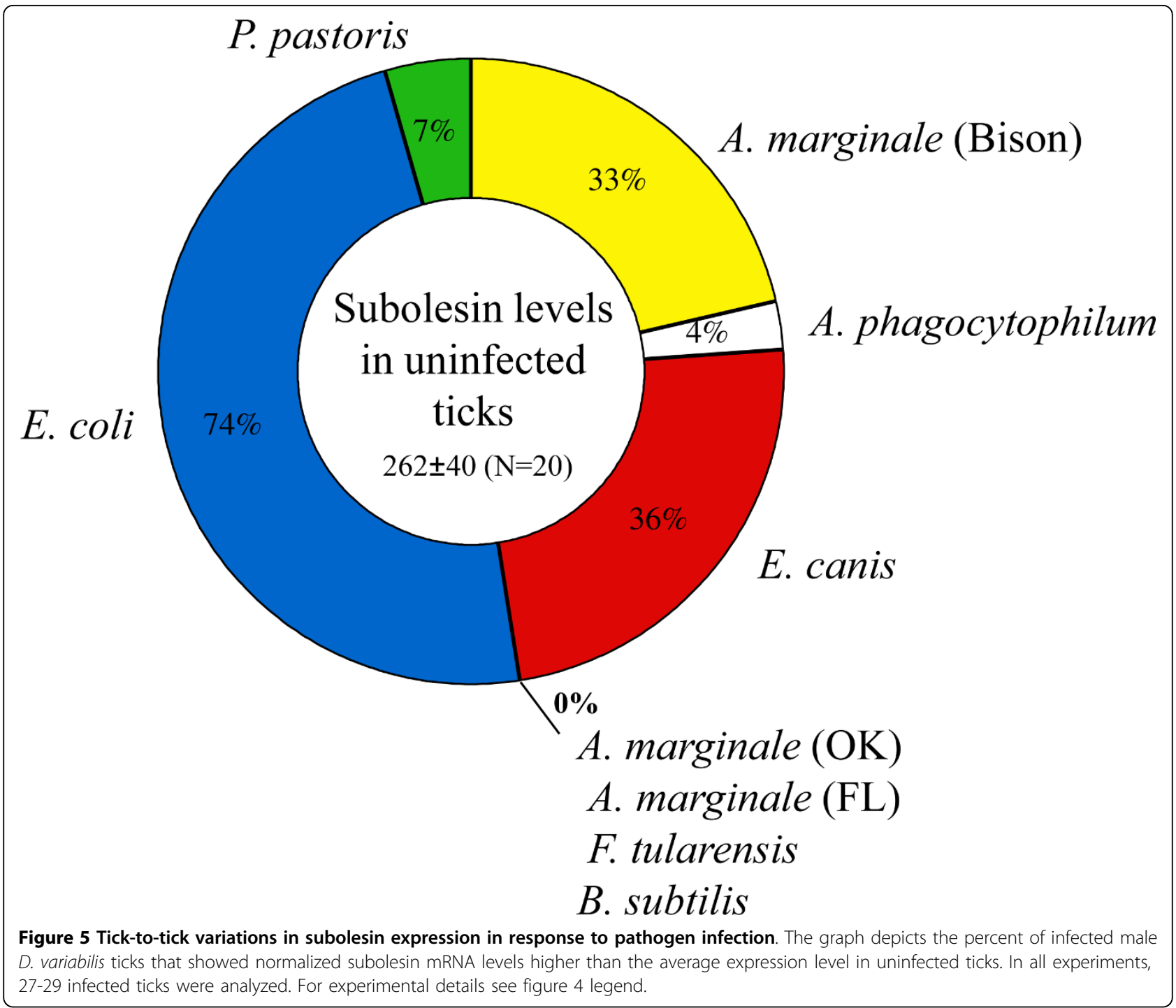

expression in ticks may include the expression of genes crucial for tissue structure and function and pathogen infection and multiplication $[8-10,19,20]$; (5) as suggested by CF experiments, unknown individual factors may affect tick subolesin expression and the capacity of ticks to mount an effective subolesin-mediated innate immune response to pathogen infection; and (6) pathogen infection by CF may differ from natural conditions and thus change the role of subolesin in pathogen infection and development. For example, $A$. marginale infection and multiplication in capillary fed ticks occurred only in the gut [28], thus differing from the natural life cycle.

For non-tick-borne pathogens, E. coli and P. pastoris, RNAi experiments suggested that subolesin did not have an effect on infection, at least after CF. However, subolesin expression was upregulated in $D$. variabilis exposed to $E$. coli, suggesting that although this pathogen may induce subolesin expression in ticks, silencing of this molecule reduced bacterial multiplication by a presently unknown mechanism. As discussed previously, tick-to-tick variations in subolesin expression in response to pathogen infection occurred for E. coli and $P$. pastoris, again suggesting that subolesin may play a role in tick innate immunity against these pathogens but this effect could be affected by unknown individual factors.

Previously, Goto et al. [21] demonstrated that akirin or relish knockdown in flies resulted in lower survival rates after Agrobacterium tumefasciens infection when compared to controls. The experiments conducted in ticks were not designed to study the effect of subolesin knockdown on infected tick survival. However, in agreement with lower infection levels in ticks after subolesin silencing, we did not observe an increase in tick mortality after experimental infection with $A$. marginale and 
other pathogens by CF. The discrepancy between the results obtained for flies and ticks after akirin/subolesin knockdown and pathogen infection could be explained by: (1) interactions that resulted from the tick-pathogen co-evolution, which are not present in A. tumefasciensinfected flies, (2) the limitations of CF to mimic natural tick feeding and infection conditions, (3) differences in the function of subolesin when compared to that of akirin in insects or (4) a combination of these factors.

\section{Conclusions}

These studies demonstrated that subolesin expression varies with pathogen infection in tick salivary glands and in the guts in response to some pathogens, thus suggesting a role of subolesin in tick innate immunity. Subolesin may activate innate immunity to certain pathogens in tick salivary glands, resulting in lower pathogen infection levels. This function may occur to a lesser extent in tick midguts and other tissues, although results in $H$. lusitanicum infected with $B$. bigemina suggest activation of innate immunity at the gut level in particular vector-pathogen systems (Figure 3B). Furthermore, previous studies have suggested a role of subolesin in different molecular pathways, including those involved in normal tick physiology and in pathogen infection and multiplication in ticks. Consequently, subolesin knockdown may affect pathogen infection in ticks directly by reducing innate immune responses resulting in higher infection levels and indirectly by affecting the expression of genes that interfere with tissue physiology and pathogen infection and multiplication.

\section{Methods \\ Ticks}

$D$. variabilis, D. andersoni and $R$. sanguineus male ticks were obtained from the Tick Rearing Facility, Department of Entomology and Plant Pathology, Oklahoma State University. Larvae and nymphs were fed on rabbits and adults were fed on sheep. The $R$. annulatus (Mercedes strain, Texas, USA) and $R$. microplus (Mozambique strain) ticks were obtained from laboratory colonies maintained on cattle at the University of Tamaulipas and the Utrecht Centre for Tick-Borne Diseases, University of Utrecht, The Netherlands, respectively. D. reticulatus ticks were also obtained from a laboratory colony at the tick rearing facility at the University of Utrecht. Larvae and nymphs were fed on rabbits and adults were fed on calves. Off-host ticks were maintained in a $12 \mathrm{hr}$ light: $12 \mathrm{hr}$ dark photoperiod at $22-25^{\circ} \mathrm{C}$ and $95 \%$ relative humidity. Animals were cared for in accordance with standards specified in the Guide for Care and Use of Laboratory Animals of each institution.

To obtain $A$. marginale-infected ticks, D. variabilis, $D$. andersoni and $R$. sanguineus, male ticks were allowed to acquisition feed (AF) for one week, during an ascending parasitemia, on a splenectomized calf experimentallyinfected with the Virginia isolate of $A$. marginale. The ticks were then removed and maintained off-host for 4 days and then allowed to transmission feed (TF) for an additional week on an uninfected calf. $R$. annulatus larvae were allowed to feed on a calf naturally-infected with A. marginale in Tamaulipas, Mexico (approximately $4 \%$ rickettsemia during tick feeding) and collected as adults after 21 days of feeding. $R$. microplus larvae and $D$. reticulatus adult male ticks were allowed to feed on an intact calf experimentally infected with the Nigeria isolate of $A$. marginale. $R$. microplus males were collected after 21 days of feeding. D. reticulatus ticks were allowed to AF for 7 days, removed and maintained 5 days off-host and then allowed to TF for an additional week on the same infected calf. Uninfected ticks were allowed to feed in the same way on uninfected calves to serve as controls. Infection of ticks with A. marginale was determined by msp4 PCR [29]. Cattle were maintained according to approved protocols and under the supervision of the respective Institutional Animal Care and Use Committees.

Questing and feeding adult ticks were collected on 27 farms located in different Sicilian regions (Palermo, Enna, Messina, Siracusa and Trapani). A total of 678 ticks were collected and analyzed for this study. Of them, 29 were questing ticks and 649 were collected from cattle, sheep, goats or dogs. Ticks were identified using morphological keys for the Italian Ixodidae [30]. The ticks were incubated for three days in the laboratory prior to dissection and RNA/DNA extraction.

\section{Identification of pathogen infection in naturally infected ticks}

DNA was extracted from individual whole tick samples using TriReagent (Sigma, St. Louis, MO, USA) following manufacturers recommendations. The DNA was resuspended in sterile distilled water and stored at $-20^{\circ} \mathrm{C}$ until used. For the initial screening, PCR analyses for Anaplasma, Ehrlichia and Rickettsia spp. were performed as described previously [24] with $1 \mu \mathrm{l}$ (0.1-10 ng) DNA using $10 \mathrm{pmol}$ of each primer and the Ready-To-Go PCR beads (Amersham, Piscataway, NJ, USA). Reactions were performed in an automated DNA thermal cycler for 35 cycles. PCR products were electrophoresed on $1 \%$ agarose gels to check the size of amplified fragments by comparison to a DNA molecular weight marker $(1 \mathrm{~Kb}$ DNA Ladder, Promega). Control reactions were done without the addition of DNA to the reaction to rule out contaminations during PCR. Reverse line blot (RLB) was used for detection of Babesia/Theileria spp. as described previously [31]. Uninfected ticks were confirmed to be negative for all pathogens analyzed. 
To identify and confirm pathogens in ticks, PCR and sequence analysis of cloned amplicons were performed for Anaplasma, Ehrlichia and Rickettsia spp. Amplified fragments were resin purified (Promega), cloned into pGEM-T vector (Promega) and sequenced in an accredited service laboratory (BaseClear, Leiden, The Netherlands) using vector specific primers. The BLAST tool was used to search the NCBI databases in order to identify sequences reported previously with identity to sequences obtained herein. Gene sequences were deposited in the GenBank with accession numbers GQ857075-GQ857078.

\section{Gene expression analysis by real-time RT-PCR in} experimentally and naturally infected ticks

Total RNA was extracted using TriReagent (Sigma) following manufacturers recommendations. In $D$. variabilis, $D$. andersoni and $R$. sanguineus male ticks experimentally infected with $A$. marginale, RNA was extracted from guts collected after AF and salivary glands collected after TF in 5 pools of 10 ticks each. $A$. marginale infection in tick guts and salivary glands was characterized by $m s p 4$ real-time RT-PCR as described previously [7]. Subolesin expression was characterized by real-time RT-PCR using species-specific oligonucleotide primers (Table 3 ) as described previously [9]. Subolesin levels were characterized in guts and salivary glands of $D$. variabilis, $D$. andersoni and $R$. sanguineus and in whole ticks experimentally infected with $A$. marginale after TF (5 pools of 10 ticks each) and in individual whole ticks naturally-infected with different pathogens. In all cases, matching groups of uninfected tick samples were analyzed concurrently for comparison. Real-time RT-PCR was done using the QuantiTec SYBR Green RT-PCR kit (Qiagen, Valencia, CA, USA) and a Bio-Rad iQ5 thermal cycler (Hercules, CA, USA) following manufacturer's recommendations. mRNA levels were normalized against tick 16S rRNA using the comparative Ct method [9,32]. Normalized subolesin mRNA levels were compared between infected and uninfected ticks by Student's t-Test $(\mathrm{P}=0.05)$. Regression analyses were conducted in Microsoft Excel to compare normalized A. marginale msp 4 and subolesin mRNA levels in the guts and salivary glands of $D$. variabilis, $D$. andersoni and $R$. sanguineus male ticks experimentally infected with A. marginale.

\section{Tick RNA interference and capillary feeding}

D. variabilis subolesin dsRNA and unrelated control Rs86 dsRNA were synthesized as described previously $[8,15,32]$, using the Access RT-PCR system (Promega, Madison, WI, USA) and the Megascript RNAi kit (Ambion, Austin, TX, USA). The dsRNA was purified and quantified by spectrometry. Male $D$. variabilis ticks were injected with approximately $0.4 \mu \mathrm{l}$ of dsRNA ( $5 \times$ $10^{10}-5 \times 10^{11}$ molecules per $\mu \mathrm{l}$ ) in the lower right quadrant of the ventral surface of the exoskeleton of ticks $[8,15]$. The injections were done on 30 ticks per group using a Hamilton syringe with a 1 -inch, 33 gauge needle. The ticks were held in a humidity chamber for 1 day after which they were allowed to feed for 3 days on a sheep prior to CF. Ticks were removed from the sheep and immobilized for CF [28]. Fifty- $\mu$ l volume capillary tubes were placed over the capitulum of the

Table 3 Oligonucleotide primers and PCR conditions for the characterization of subolesin and pathogen-specific gene expression

\begin{tabular}{|c|c|c|}
\hline Gene description $^{a}$ & Upstream/downstream primer sequences $\left(5^{\prime}-3^{\prime}\right)$ & PCR annealing conditions \\
\hline D. variabilis subolesin [9] & $\begin{array}{l}\text { CCAGCCTCTGTTCACCTTTC } \\
\text { CCGCTTCTGAATTTGGTCAT }\end{array}$ & $\begin{array}{l}54^{\circ} \mathrm{C} \\
30 \mathrm{sec}\end{array}$ \\
\hline R. microplus subolesin [9] & $\begin{array}{l}\text { CACAGTCCGAGTGGCAGAT } \\
\text { GATGCACTGGTGACGAGAGA }\end{array}$ & $\begin{array}{l}55^{\circ} \mathrm{C} \\
30 \mathrm{sec}\end{array}$ \\
\hline A. marginale msp4 [29] & $\begin{array}{l}\text { GGGAGCTCCTATGAATTACAGAGAATTGTTTAC } \\
\text { CCGGATCCTTAGCTGAACAGGAATCTTGC }\end{array}$ & $\begin{array}{l}60^{\circ} \mathrm{C} \\
1 \mathrm{~min} \\
\end{array}$ \\
\hline A. phagocytophilum msp4 [9] & $\begin{array}{l}\text { GACGTGCTGCACACAGATTT } \\
\text { CTCATCAAATAGCCCGTGGT }\end{array}$ & $\begin{array}{l}54^{\circ} \mathrm{C} \\
1 \mathrm{~min}\end{array}$ \\
\hline E. canis $16 \mathrm{~S}(\mathrm{M} 73221)$ & $\begin{array}{l}\text { GTGGCAGACGGGTGAGTAAT } \\
\text { GCTGATCGTCCTCTCAGACC }\end{array}$ & $\begin{array}{l}57^{\circ} \mathrm{C} \\
30 \mathrm{sec}\end{array}$ \\
\hline B. subtilis dal [35] & $\begin{array}{l}\text { AATTGAAAGGGACCGACATC- } \\
\text { TTAATGGTTCGAGCCTTCC }\end{array}$ & $\begin{array}{l}59^{\circ} \mathrm{C} \\
30 \mathrm{sec}\end{array}$ \\
\hline E. coli $d x s[36]$ & $\begin{array}{l}\text { CGAGAAACTGGCGATCCTTA } \\
\text { CTTCATCAAGCGGTTCACA }\end{array}$ & $\begin{array}{l}60^{\circ} \mathrm{C} \\
30 \mathrm{sec}\end{array}$ \\
\hline P. pastoris CTA 1 (AB472085) & $\begin{array}{l}\text { CCTGAAGGACGCCAATATGT } \\
\text { GCTTTCCAGCCTCTTCATTG }\end{array}$ & $\begin{array}{l}57^{\circ} \mathrm{C} \\
30 \mathrm{sec}\end{array}$ \\
\hline Tick 16S rRNA [9] & $\begin{array}{l}\text { GACAAGAAGACCCTA } \\
\text { ATCCAACATCGAGGT }\end{array}$ & $\begin{array}{l}42^{\circ} \mathrm{C} \\
30 \mathrm{sec}\end{array}$ \\
\hline
\end{tabular}

${ }^{a}$ When published, references are shown for oligonucleotide sequences. When designed for this study, GenBank accession numbers are shown in parenthesis. 
ticks to feed them with the pathogen containing tick meal (Table 2). CF was done for 3 days with daily changes of capillary tubes containing fresh tick meal. Whole individual ticks were then dissected and used for DNA/RNA extraction to determine pathogen infection levels by real-time PCR and subolesin mRNA levels by real-time RT-PCR using pathogen-specific gene sequences (Table 3) and subolesin primers, respectively, as described above. Subolesin and pathogen-specific gene normalized $\mathrm{Ct}$ values were compared between subolesin dsRNA and control Rs86 dsRNA injected ticks by Student's t-test $(\mathrm{P}=0.05)$. For $F$. tularensis, dissected tick tissues were homogenized, centrifuged and supernatants plated to count pathogen colony forming units (CFU) per tick and to compare CFU between subolesin dsRNA and control Rs86 dsRNA injected ticks by Student's t-test $(P=0.05)$. Regression analyses were conducted in Microsoft Excel to compare normalized pathogen infection levels and subolesin mRNA levels.

\begin{abstract}
Acknowledgements
We thank Holly Evers (OSU) and Dollie Clawson (OSU) and Franco Ferrara (IZS) for supplying the B. subtilis strain and technical assistance, respectively. This research was supported by the Ministerio de Ciencia e Innovación, Spain (project BFU2008-01244/BMC), the INIA, Spain (project FAU2008-0001400-00), the Ministry of Health, Italy (project IZS SI 10-06), the CSIC intramural projects 2008301249 and PA1002025 to JF, the Oklahoma Agricultural Experiment Station (project 1669), the Walter R. Sitlington Endowed Chair for Food Animal Research (K. M. Kocan, Oklahoma State University) and facilitated by ICTTD-3, financed by the International Cooperation Program of the European Union, coordination action project No. 510561. M. Villar was funded by the JAE-DOC program (CSIC-FSE), Spain.
\end{abstract}

\section{Author details \\ 'Department of Infectious Diseases and Immunology, Utrecht Centre for Tick-borne Diseases (UCTD), Faculty of Veterinary Medicine, Utrecht University, Yalelaan 1, 3584CL, Utrecht, The Netherlands. ${ }^{2}$ Intituto Zooprofilattico Sperimentale della Sicilia, Via G. Marinuzzi n³, 90129 Palermo, Sicily, Italy. ${ }^{3}$ Department of Veterinary Pathobiology Center for Veterinary Health Sciences, Oklahoma State University, Stillwater, OK 74078, USA. ${ }^{4}$ Instituto de Investigación en Recursos Cinegéticos IREC (CSIC-UCLM-JCCM), Ronda de Toledo s/n, 13005 Ciudad Real, Spain. ${ }^{5}$ Facultad de Medicina Veterinaria y Zootecnia, Universidad Autónoma de Tamaulipas, Km. 5 carretera Victoria-Mante, CP 87000 Ciudad Victoria, Tamaulipas, Mexico. ${ }^{6}$ Department of Veterinary Tropical Diseases, Faculty of Veterinary Science, University of Pretoria, Private Bag X04, 0110, Onderstepoort, South Africa.}

\section{Authors' contributions}

JF conceived and designed the experiments. JF, AT, SC, KMK and FJ coordinated the experiments. KMK, ZZ, AT, RM, AA, SS, KMK, EB, MV, RCG, RIM, GLB and AMN performed the experiments. ZZ, AT, RM and JF analyzed the data. JF, KMK, ZZ, AT and RM wrote the paper. All the authors read and approved the final manuscript.

Received: 3 September 2009

Accepted: 19 February 2010 Published: 19 February 2010

\section{References}

1. de la Fuente J, Estrada-Pena A, Venzal JM, Kocan KM, Sonenshine DE: Overview: Ticks as vectors of pathogens that cause disease in humans and animals. Front Biosci 2008, 13:6938-6946.

2. Kocan KM, de la Fuente J, Blouin EF, Garcia-Garcia JC: Anaplasma marginale (Rickettsiales: Anaplasmataceae): recent advances in defining host-pathogen adaptations of a tick-borne rickettsia. Parasitology 2004, 129(Suppl):S285-300.

3. Dumler JS, Barbet AF, Bekker CP, Dasch GA, Palmer GH, Ray SC, Rikihisa Y, Rurangirwa FR: Reorganization of genera in the families Rickettsiaceae and Anaplasmataceae in the order Rickettsiales: unification of some species of Ehrlichia with Anaplasma, Cowdria with Ehrlichia and Ehrlichia with Neorickettsia, descriptions of six new species combinations and designation of Ehrlichia equi and 'HGE agent' as subjective synonyms of Ehrlichia phagocytophila. Int I Syst Evol Microbiol 2001, 51(Pt 6):2145-2165.

4. Kocan KM: Development of Anaplasma marginale in ixodid ticks: coordinated development of a rickettsial organism and its tick host. England: Ellis Horwood Ltd 1986.

5. Kocan KM, Stiller D, Goff WL, Claypool PL, Edwards W, Ewing SA, McGuire TC, Hair JA, Barron SJ: Development of Anaplasma marginale in male Dermacentor andersoni transferred from parasitemic to susceptible cattle. Am J Vet Res 1992, 53(4):499-507.

6. Blouin EF, Kocan KM: Morphology and development of Anaplasma marginale (Rickettsiales: Anaplasmataceae) in cultured Ixodes scapularis (Acari: Ixodidae) cells. J Med Entomol 1998, 35(5):788-797.

7. de la Fuente J, Blouin EF, Manzano-Roman R, Naranjo V, Almazan C, Perez de la Lastra JM, Zivkovic Z, Jongejan F, Kocan KM: Functional genomic studies of tick cells in response to infection with the cattle pathogen, Anaplasma marginale. Genomics 2007, 90(6):712-722.

8. de la Fuente J, Almazan C, Blouin EF, Naranjo V, Kocan KM: Reduction of tick infections with Anaplasma marginale and A. phagocytophilum by targeting the tick protective antigen subolesin. Parasitol Res 2006, 100(1):85-91.

9. de la Fuente J, Blouin EF, Manzano-Roman R, Naranjo V, Almazan C, Perez de la Lastra JM, Zivkovic Z, Massung RF, Jongejan F, Kocan KM: Differential expression of the tick protective antigen subolesin in anaplasma marginale- and A. phagocytophilum-infected host cells. Ann N Y Acad Sci 2008, 1149:27-35.

10. Kocan KM, Zivkovic Z, Blouin EF, Naranjo V, Almazan C, Mitra R, de la Fuente J: Silencing of genes involved in Anaplasma marginale-tick interactions affects the pathogen developmental cycle in Dermacentor variabilis. BMC Dev Biol 2009, 9(1):42.

11. Zivkovic Z, Blouin EF, Manzano-Roman R, Almazán C, Naranjo V, Massung RF, Jongejan F, Kocan KM, de la Fuente J: Anaplasma phagocytophilum and $A$. marginale elicit different gene expression responses in ticks and cultured tick cells. Comparative and Functional Genomics 2009, 9.

12. Almazan C, Kocan KM, Bergman DK, Garcia-Garcia JC, Blouin EF, de la Fuente J: Identification of protective antigens for the control of Ixodes scapularis infestations using cDNA expression library immunization. Vaccine 2003, 21(13-14):1492-1501.

13. Almazan C, Kocan KM, Blouin EF, de la Fuente J: Vaccination with recombinant tick antigens for the control of Ixodes scapularis adult infestations. Vaccine 2005, 23(46-47):5294-5298.

14. Almazan C, Blas-Machado U, Kocan KM, Yoshioka JH, Blouin EF, Mangold AJ, de la Fuente J: Characterization of three Ixodes scapularis cDNAs protective against tick infestations. Vaccine 2005, 23(35):4403-4416.

15. de la Fuente J, Almazan C, Blas-Machado U, Naranjo V, Mangold AJ, Blouin EF, Gortazar C, Kocan KM: The tick protective antigen, 4D8, is a conserved protein involved in modulation of tick blood ingestion and reproduction. Vaccine 2006, 24(19):4082-4095.

16. de la Fuente J, Almazan C, Naranjo V, Blouin EF, Meyer JM, Kocan KM: Autocidal control of ticks by silencing of a single gene by RNA interference. Biochem Biophys Res Commun 2006, 344(1):332-338.

17. Nijhof AM, Taoufik A, de la Fuente J, Kocan KM, de Vries E, Jongejan F: Gene silencing of the tick protective antigens, Bm86, Bm91 and subolesin, in the one-host tick Boophilus microplus by RNA interference. Int J Parasitol 2007, 37(6):653-662.

18. Kocan KM, Manzano-Roman R, de la Fuente J: Transovarial silencing of the subolesin gene in three-host ixodid tick species after injection of replete females with subolesin dsRNA. Parasitol Res 2007, 100(6):1411-1415.

19. de la Fuente J, Maritz-Olivier C, Naranjo V, Ayoubi P, Nijhof AM, Almazan C, Canales M, Perez de la Lastra JM, Galindo RC, Blouin EF, et al: Evidence of the role of tick subolesin in gene expression. BMC Genomics 2008, 9(1):372. 
20. Galindo RC, Doncel-Perez E, Zivkovic Z, Naranjo V, Gortazar C, Mangold AJ, Martin-Hernando MP, Kocan KM, de la Fuente J: Tick subolesin is an ortholog of the akirins described in insects and vertebrates. Dev Comp Immunol 2009, 33(4):612-617.

21. Goto A, Matsushita K, Gesellchen V, El Chamy L, Kuttenkeuler D, Takeuchi O, Hoffmann JA, Akira S, Boutros M, Reichhart JM: Akirins are highly conserved nuclear proteins required for NF-kappaB-dependent gene expression in drosophila and mice. Nat Immunol 2008, 9(1):97-104

22. Mangold AJ, Galindo RC, de la Fuente J: Response to the commentary of D. Macqueen on: Galindo RC, Doncel-Pérez E, Zivkovic Z, Naranjo V, Gortazar C, Mangold AJ, et al. Tick subolesin is an ortholog of the akirins described in insects and vertebrates [Dev. Comp. Immunol. 33 (2009) 612-617]. Developmental and Comparative Immunology 2009, 33:878-879.

23. Ueti MW, Reagan JO Jr, Knowles DP Jr, Scoles GA, Shkap V, Palmer GH: Identification of midgut and salivary glands as specific and distinct barriers to efficient tick-borne transmission of Anaplasma marginale. Infect Immun 2007, 75(6):2959-2964.

24. Torina A, Vicente J, Alongi A, Scimeca S, Turla R, Nicosia S, Di Marco V, Caracappa S, de la Fuente J: Observed prevalence of tick-borne pathogens in domestic animals in Sicily, Italy during 2003-2005. Zoonoses Public Health 2007, 54(1):8-15.

25. Kocan KM, de la Fuente J, Blouin EF: Advances toward understanding the molecular biology of the Anaplasma-tick interface. Front Biosci 2008, 13:7032-7045.

26. Kocan KM, de la Fuente J, Manzano-Roman R, Naranjo V, Hynes WL, Sonenshine DE: Silencing expression of the defensin, varisin, in male Dermacentor variabilis by RNA interference results in reduced Anaplasma marginale infections. Exp App/ Acarol 2008, 46(1-4):17-28.

27. Goethert HK, Telford SR: Nonrandom distribution of vector ticks (Dermacentor variabilis) infected by Francisella tularensis. PLOS Pathog 2009, 5(2):e1000319.

28. Kocan KM, Yoshioka J, Sonenshine DE, de la Fuente J, Ceraul SM, Blouin EF, Almazan C: Capillary tube feeding system for studying tick-pathogen interactions of Dermacentor variabilis (Acari: Ixodidae) and Anaplasma marginale (Rickettsiales: Anaplasmataceae). J Med Entomol 2005, 42(5):864-874.

29. de la Fuente J, Garcia-Garcia JC, Blouin EF, McEwen BR, Clawson D, Kocan KM: Major surface protein 1a effects tick infection and transmission of Anaplasma marginale. Int J Parasitol 2001, 31(14):1705-1714.

30. G M: Fauna D'Italia. Acari: Ixodida. Calderini. Bologna, Italy 1998.

31. Schnittger L, Yin H, Qi B, Gubbels MJ, Beyer D, Niemann S, Jongejan F, Ahmed JS: Simultaneous detection and differentiation of Theileria and Babesia parasites infecting small ruminants by reverse line blotting. Parasitol Res 2004, 92(3):189-196.

32. de la Fuente J, Almazan C, Naranjo V, Blouin EF, Kocan KM: Synergistic effect of silencing the expression of tick protective antigens 4D8 and Rs 86 in Rhipicephalus sanguineus by RNA interference. Parasitol Res 2006, 99(2):108-113.

33. de la Fuente J, Ruybal P, Mtshali MS, Naranjo V, Shuqing L, Mangold AJ, Rodriguez SD, Jimenez R, Vicente J, Moretta R, et al: Analysis of world strains of Anaplasma marginale using major surface protein 1a repeat sequences. Vet Microbiol 2007, 119(2-4):382-390.

34. Asanovich KM, Bakken JS, Madigan JE, Aguero-Rosenfeld M, Wormser GP, Dumler JS: Antigenic diversity of granulocytic Ehrlichia isolates from humans in Wisconsin and New York and a horse in California. J Infect Dis 1997, 176(4):1029-1034

35. Li Z, Zhao X, Zhou C, Gu B, Frankel FR: A truncated Bacillus subtilis dal gene with a $3^{\prime}$ ssrA gene tag regulates the growth and virulence of racemase-deficient Listeria monocytogenes. Microbiology 2006, 152(Pt 10):3091-3102.

36. Lee C, Kim J, Shin SG, Hwang S: Absolute and relative QPCR quantification of plasmid copy number in Escherichia coli. J Biotechnol 2006, 123(3):273-280.

doi:10.1186/1471-2172-11-7

Cite this article as: Zivkovic et al:: Subolesin expression in response to pathogen infection in ticks. BMC Immunology 2010 11:7.

\section{Submit your next manuscript to BioMed Central and take full advantage of:}

- Convenient online submission

- Thorough peer review

- No space constraints or color figure charges

- Immediate publication on acceptance

- Inclusion in PubMed, CAS, Scopus and Google Scholar

- Research which is freely available for redistribution

Submit your manuscript at www.biomedcentral.com/submit 